\author{
Available online at https://www.rjtl.org \\ Volume: 2, Issue: 1, 71-76, 2021 \\ ISSN: 2708-3632 \\ DOI: https://doi.org/10.46590/rjtl.2021.02012
}

\title{
Application of Nano Sericin Finish on Polyester Fabric
}

\author{
K.V.Arunkumar, A.Deepika Priya, K.Gomathi \\ Assistant Professor, Department of Costume Design and Fashion, Kongu Arts and Science College (Autonomous), Erode, \\ Tamilnadu, India.
}

\section{Paper History}

Received: December 2020

Accepted: January 2021

Published: February 2021

Corresponding Author

K.V.Arunkumar

kvaruncdf@gmail.com
Abstract: Textiles of today are materials with applications in almost all our activities, Silk is a natural protein fiber used by mankind for more centuries. The silk fiber mainly contains two types of proteins they are fibroin and sericin. The sticky protein sericin is removed in the degumming process and discarded as wastewater in silk fiber production industry. In this study, the wastewater sericin is collected from the industry and recovered the sericin by various extraction methods. Then convert into nano sericin particles and the nanosericin is applied to the polyester fabric to improve the absorbency property of the fabric.

Keywords: Nanotechnology, Polyester, Sericin, Silk

Citation: K.V.Arunkumar, A.Deepika Priya, K.Gomathi., Application of Nano Sericin Finish on Polyester Fabric. Research Journal of Textile and Leather, 2(1), 71-76, 2021.

\section{INTRODUCTION}

Silk is the only natural filament fiber. It consists of two types of proteins in their structure. the inner core fibrous protein is termed as fibroin and the outer sticky protein is termed as sericin. Degumming process plays a vital role in the extraction of silk fiber from the cocoon.

During the process, the outer sericin layer of the fiber is removed and discarded as wastewater. The sericin is a valuable protein contains essential amino acids. After the removal of sericin the fiber becomes soft and lustrous. Sericin has some great properties such as antibacterial, UV resistant, moisture absorbency, easily soluble in hot water. The wastewater from the silk industry is collected and utilized for the recovery of the sericin. The recovered sericin is converted into nanoparticles for the wide range of applications. Nanosericin has excellent water absorbency property when finished in fabrics and have many other valueadded properties also.

Nanosericin has a wide range of application for various industries like pharmaceutical, medical and many beauty care products. It acts as an anti-oxidant and used for many face creams. It plays a major role in the cosmetics industry. It is used as an antimicrobial agent for many studies. In this study, the nano sericin finish is applied to the polyester fabric to improve its absorbency property.

\section{EXPERIMENTAL PROCEDURE}

\subsection{Selection of Fabric}

Polyester is the widely used manmade fiber around the world. It is majorly used in the textile industry and packaging industry due to its excellent dimensional stability and Durability. Polyester fiber can be blended with cotton fiber to reduce the shrinkage property. Polyester fibers have high stainresistance property. The sustainability of the fiber makes a way for its reuse. The main disadvantage of the fiber in the textile industry is its absorbency property and comfort property. To improve the absorbency property hydrophilic finishes are applied. Therefore a synthetic polyester fabric was purchased and used for the study.

\subsection{Collection of Silk Degummed Water}

To remove the sericin from the silk cocoons, several methods were carried out by all silk industries called a degumming process of silk cocoons. The degummed silk wastewater was collected from small scale silk industry unit, Padiur Sarvodhaya Sangam, Kangayem, Tamil Nadu. The degummed water was stored in a cold room to avoid the tarnish of stored water while kept in the normal environment.

\subsection{Extraction of Sericin}

The collected silk degummed wastewater was used for the various sericin extraction methods. Some of them are direct sunlight method, centrifuge method, heating mantle method and spray dryer method. 
In this study, the heating mantle and centrifuge method were used. The collected silk wastewater of $250 \mathrm{ml}$ was centrifuged at 4000rpm for about 10 mins and then removes the suspended particles. The solution was analyzed for sericin protein by UVvisible spectroscopy and SEM analysis and protein estimation by Lowry's method. Then, the remaining crude sericin water was stored in a room temperature for further use.

\subsection{Preparation of Nanosericin}

Nanosericin was prepared with the help of silver nitrate (AgNO3). Initially, the $3 \mathrm{~g}$ of $\mathrm{AgNO} 3$ was dissolved in distilled water of $90 \mathrm{ml}$ and the silver sericin solutions of $10 \mathrm{ml}$ were taken. Silver nitrate solution was added to silk sericin water and stirs the solution with the equipment of magnetic stirrer. AgNO3 was poured into the beaker by using a burette and the mixture was stirred at room temperature over 4 hours. The transparent solution turned yellow which indicated the formation of silver nanoparticles (nano sericn).

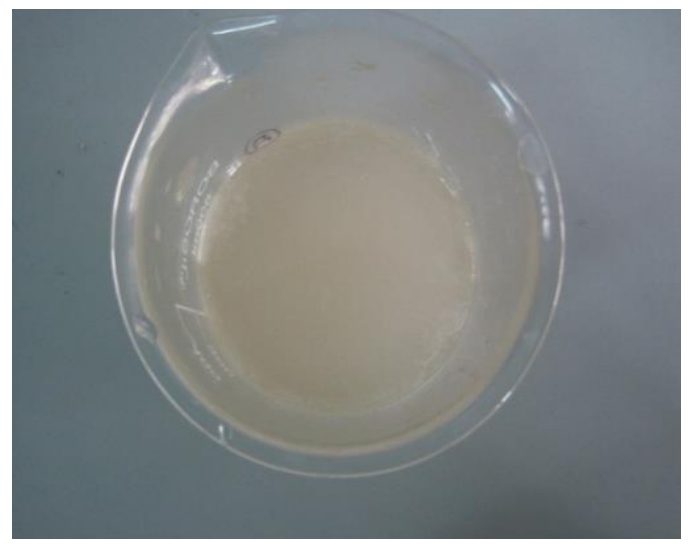

Plate 1: Sericin

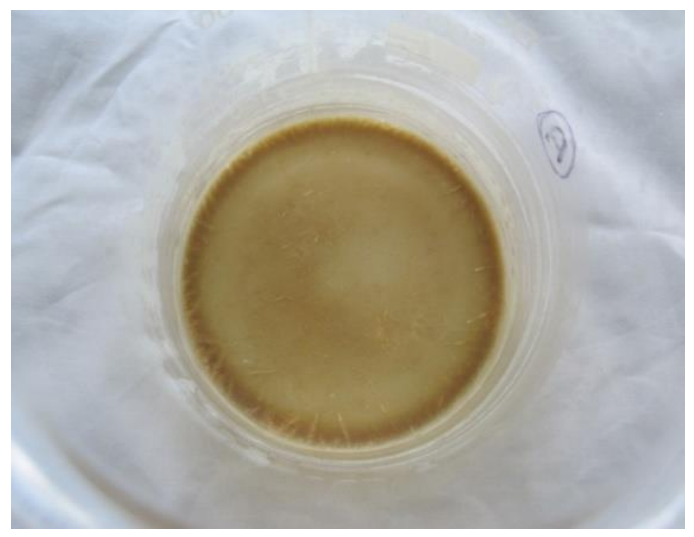

Plate 2: Nano Sericin

\subsubsection{Estimation of Protein}

The estimation of protein was analyzed by Lowry method. The Bovine Serum Albumin concentration range from 0.2 to $1.0 \mathrm{ml}$ was taken in test tubes for protein concentration standard. Distilled water is added to make it uniform to $1.0 \mathrm{ml}$. the equal amount of sericin is taken in another test tube. The $0.5 \mathrm{ml}$ reagent was added to all and mixed well. Then it was incubated 10 minutes at room temperature. $0.5 \mathrm{ml}$ of FolinCiocalteau reagent was added and incubated at dark for 30 minutes. The optical density of samples was measured at $660 \mathrm{~nm}$. Absorbance was plotted against protein concentration to get the standard calibration graph and the sericin.

\subsubsection{Particles Size Analysis}

The sericin solution and nano sericin solution were analyzed for particle size using NPA152-31A Zetatrac particle size analyzer. $5 \mathrm{ml}$ of sericin solution and nano sericin solution was loaded in sample loader with the help of a syringe. The size of the article is analyzed by the emission of $780 \mathrm{~nm}$ wavelength from a laser diode.

\subsubsection{UV-Visible Spectroscopy}

UV-Visible Spectroscopy is a technique to identify the molecules absorb the light in the UV visible wavelength. The $\mathrm{Ag}^{2+}$ ions were monitored after diluting a small amount of the sample in distilled water. UV- visible spectroscopy was carried out by an FLCO 150 UV visible spectrum.

\subsubsection{SEM Analysis}

Scanning Electron Microscopy is a type of test that scans a sample to produce a magnified image with an electron beam for analysis. The high-resolution images are used for the analysis of surface modification of the fibers. In this study, SEM analysis is used to identify the nanoparticles in the surface of the fiber. The sample was analyzed under Hitachi SV-1500 scanning electron microscope

\subsection{Water Absorbency Finish}

Polyester is the most widely fibre used in the fashion industry for its resistance and quick-drying properties. It is mostly used swimwear due to its low moisture absorbency property. But the low comfort property the usage of the polyester fiber has limited when compared to cotton, so to improve the comport property of the polyester fiber various water absorbency finishes are used. Hence to overcome this difficulty the fabric was treated with the natural availability of sericin to increase the water absorbency of polyester fabric.

\subsubsection{Finishing Procedure}

The water absorbency finish was given to the fabric by the exhaustion method. The samples were kept immersed in the solution of 1.20 ratios at $80^{\circ} \mathrm{c}$ for 15 minutes in the water bath. After finishing, the samples were removed, squeezed, and dried at room temperature. 


\subsection{Nomenclature}

The following tables deal with the nomenclature of samples.

Table 1. Nomenclature of Samples

\begin{tabular}{lll}
\hline S.No & Samples & Description \\
\hline 1. & UTS & Untreated sample \\
2. & STS & Sericin treated sample \\
3. & NTSS & $\begin{array}{l}\text { Nano treated sericin } \\
\text { sample }\end{array}$ \\
\hline
\end{tabular}

\subsection{Water Absorbency Test}

The water absorbency test is carried out to identify the time taken for a drop of water to be completely absorbed into the fabric. The sample fabric is mounted on an embroidery frame and placed below the burette. Stop clock is used to record the time taken for a drop of water absorbs completed by the fabric. The recorded time is termed as water absorbency time.

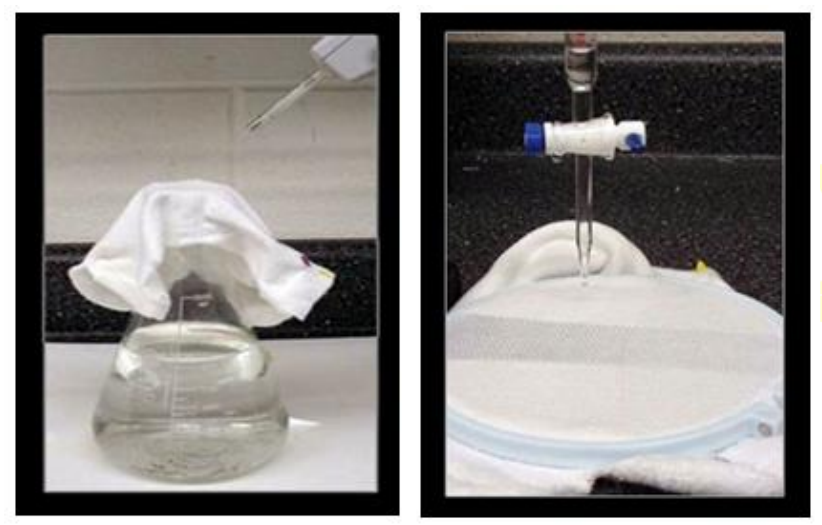

Plate 3. Water Absorbency Test

\section{RESULTS AND DISCUSSION}

\subsection{Protein Estimation}

The protein estimation was done by Lowry method. The Bovine Serum Albumin concentration was taken for protein concentration stand. The concentration of the proteins was estimated against BSA and table 2 shows the result.

\subsection{UV-Visible Spectroscopy}

The mixture of sericin and silver nitrate solution was visually observed. The solution colour was changed from milky to yellowish mild black. Reductions of silver into AgNps are marked by colour change. The reduction of $\mathrm{Ag}+$ aqueous solution was monitored. The strong surface Plasmon resonance band appears at the range of $214.9 \mathrm{~nm}$.

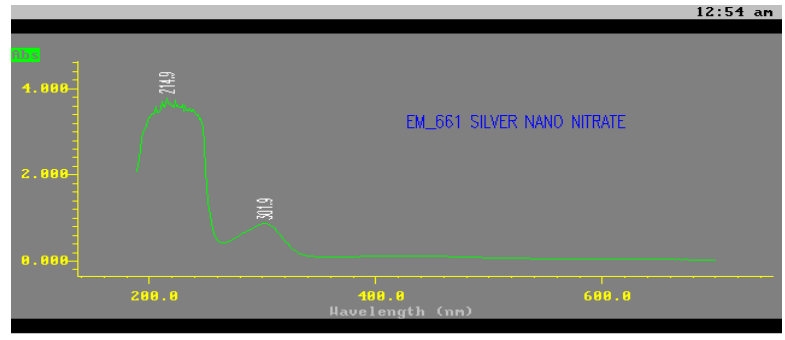

Figure 1. UV- Spectroscopy

\subsection{Particle Size Analysis}

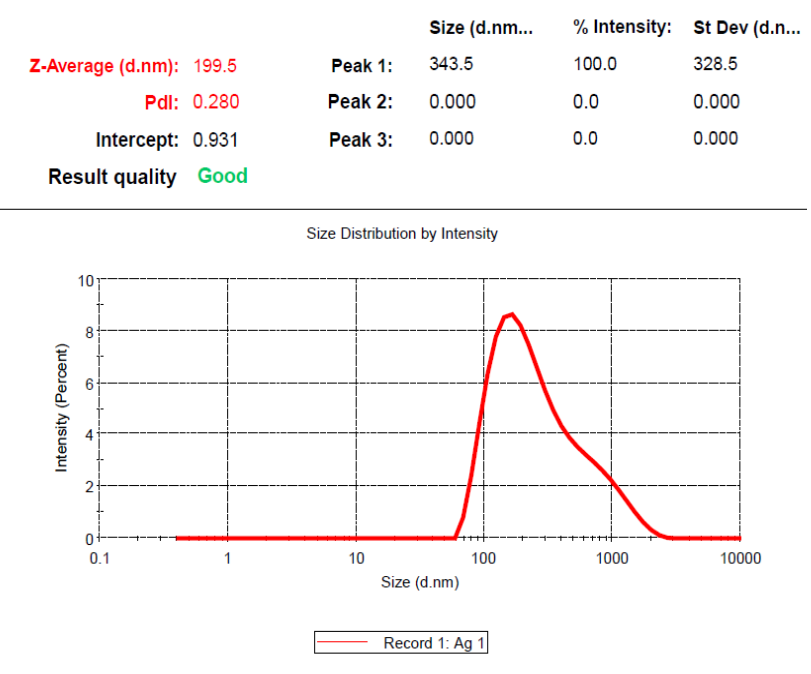

Figure 2. Particle Size Analysis

The results show that the particles obtained through ultrasonication had an average particle size of 328.5$343.5 \mathrm{~nm}$, while the sericin treated with urea reduced the sericin to a much smaller size. The average particle size obtained through the urea method was one $\mathrm{nm}$.

\subsection{SEM Analysis}

The scanning electron microscopic (SEM) was done using the Hitachis-4500 SEM machine. The magnification was done in $30000-40000 \mathrm{X}$. the study shows the surface modification of AgNps synthesized by sericin. The surface shows rough confirms the presence of AgNPs. The particles are spherical. The SEM pattern shows uniformly distributed silver nanoparticles on the surface of the fabric.

\subsection{Water Absorbency Test}

The water absorption of the sample results is given in table 3. It is clear from table 3, the water absorbency for finished polyester fabric with nano sericin and sericin was very good when compared to unfinished fabric. The time taken to absorb the water for the finished fabric is below 1.5 minutes. 

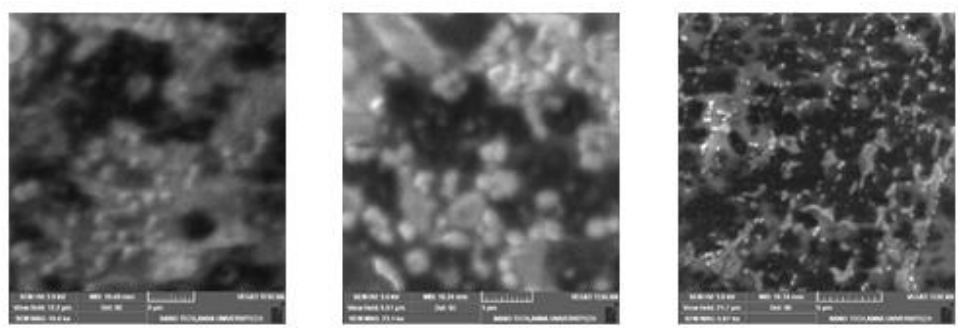

Plate 4. SEM Analysis

Table 2. Protein Estimation

\begin{tabular}{cllllllll}
\hline S.No & Particulars & B & S1 & S2 & S3 & S4 & S5 & T \\
\hline 1 & The volume of working standard (in ml) & - & 0.2 & 0.4 & 0.6 & 0.8 & 1.0 & - \\
2 & Concentration & - & 20 & 40 & 60 & 80 & 100 & - \\
3 & The volume of diluted sericin (in $\mathrm{ml})$ & - & - & - & - & - & - & 0.1 \\
4 & The volume of distilled water (in $\mathrm{ml})$ & 1 & 0.8 & 0.6 & 0.4 & 0.4 & 0.0 & 0.9 \\
5 & The volume of Lowry's reagent (in ml) & 4.5 & 4.5 & 4.5 & 4.5 & 4.5 & 4.5 & 4.5 \\
\hline All the test tubes were allowed to stand at room temperature for 10 minutes \\
\hline 6
\end{tabular}

All the test tubes were allowed to stand at room temperature for 10 minutes

\begin{tabular}{cllllllll}
\hline 7 & Optical density at $650 \mathrm{~nm}$ & 0.00 & 0.01 & 0.02 & 0.03 & 0.04 & 0.05 & 0.05 \\
\hline \multirow{2}{*}{ S.No } & Particulars & $\mathrm{B}$ & $\mathrm{S} 1$ & $\mathrm{~S} 2$ & $\mathrm{~S} 3$ & $\mathrm{~S} 4$ & $\mathrm{~S} 5$ & $\mathrm{~T}$ \\
\hline 1 & The volume of working standard (in $\mathrm{ml})$ & - & 0.2 & 0.4 & 0.6 & 0.8 & 1.0 & - \\
2 & Concentration & - & 20 & 40 & 60 & 80 & 100 & - \\
3 & The volume of diluted sericin (in $\mathrm{ml})$ & - & - & - & - & - & - & 0.1 \\
4 & The volume of distilled water (in ml) & 1 & 0.8 & 0.6 & 0.4 & 0.4 & 0.0 & 0.9 \\
5 & The volume of Lowry's reagent (in $\mathrm{ml})$ & 4.5 & 4.5 & 4.5 & 4.5 & 4.5 & 4.5 & 4.5 \\
\hline
\end{tabular}

All the test tubes were allowed to stand at room temperature for 10 minutes

\begin{tabular}{cllllllll}
\hline 6 & Volume of Folins-Ciocalteau & 0.5 & 0.5 & 0.5 & 0.5 & 0.5 & 0.5 & 0.5 \\
\hline $\begin{array}{c}\text { All the test tubes were allowed to stand at room temperature for } 10 \\
\text { minutes }\end{array}$ & & & & \\
\hline 7 & Optical density at $650 \mathrm{~nm}$ & $\mathrm{~B}$ & $\mathrm{~S} 1$ & $\mathrm{~S} 2$ & $\mathrm{~S} 3$ & $\mathrm{~S} 4$ & $\mathrm{~S} 5$ & $\mathrm{~T}$ \\
\hline \multirow{2}{*}{ S.No } & Particulars & -0.01 & 0.02 & 0.03 & 0.04 & 0.05 & 0.05 \\
\hline 1 & The volume of working standard (in ml) & - & 0.2 & 0.4 & 0.6 & 0.8 & 1.0 & - \\
2 & Concentration & - & 20 & 40 & 60 & 80 & 100 & - \\
3 & The volume of diluted sericin (in ml) & - & - & - & - & - & - & 0.1 \\
4 & The volume of distilled water (in ml) & 1 & 0.8 & 0.6 & 0.4 & 0.4 & 0.0 & 0.9 \\
5 & The volume of Lowry's reagent (in ml) & 4.5 & 4.5 & 4.5 & 4.5 & 4.5 & 4.5 & 4.5 \\
\hline
\end{tabular}

All the test tubes were allowed to stand at room temperature for 10 minutes

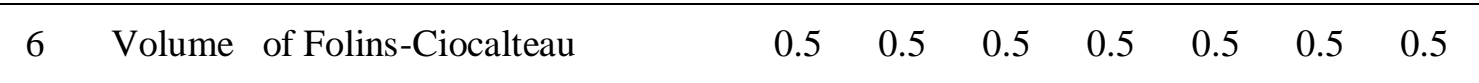

All the test tubes were allowed to stand at room temperature for 10 minutes

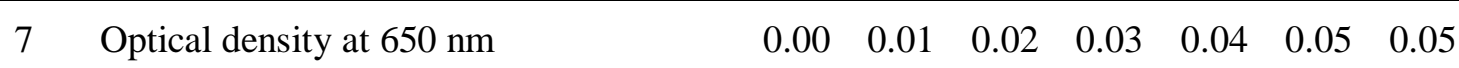




\subsection{Fabric Weight}

The fabric weight of the sample results is given in the below table 4 .

Table 4: Fabric Weight Test

\begin{tabular}{llll}
\hline Samples & $\begin{array}{l}\text { Mean in } \\
\text { g/sq.yard }\end{array}$ & $\begin{array}{l}\text { Loss or } \\
\text { gain } \\
\text { over } \\
\text { original }\end{array}$ & $\begin{array}{l}\text { Percentage loss } \\
\text { or gain }\end{array}$ \\
\hline UT & 82 & - & - \\
STS & 82.7 & 0.7 & 0.846 \\
NTSS & 83.5 & 1.5 & 1.796 \\
\hline
\end{tabular}

3.7. Abrasion Resistance

The abrasion resistance of the treated samples are given below

Table 5: Abrasion Resistance

\begin{tabular}{lllll}
\hline S.No & Samples & $\begin{array}{l}\text { Mean } \\
\text { value } \\
\text { in } \\
\text { gms }\end{array}$ & $\begin{array}{l}\text { Loss or } \\
\text { gain } \\
\text { over } \\
\text { original }\end{array}$ & $\begin{array}{l}\text { Percentage } \\
\text { of loss or } \\
\text { gain }\end{array}$ \\
\hline 1. & UT & 0.003 & - & - \\
2. & STS & 0.002 & 0.001 & 50 \\
3. & NTSS & 0.002 & 0.001 & 50 \\
\hline
\end{tabular}

It is clear from the above table that the finished fabric has good abrasion resistance when compared to the nano-treated sericin sample with a value of 0.002 grams.

\subsection{Fabric Stiffness}

The fabric stiffness for untreated and treated samples is given below.

Table 6. Fabric Stiffness-Warp Direction

\begin{tabular}{llll}
\hline Samples & $\begin{array}{l}\text { Mean } \\
\text { value in } \\
\text { cms }\end{array}$ & $\begin{array}{l}\text { Loss or } \\
\text { gain over } \\
\text { original }\end{array}$ & $\begin{array}{l}\text { Percentage } \\
\text { loss or } \\
\text { gain }\end{array}$ \\
\hline UT & 0.73 & - & - \\
STS & 1.08 & 0.35 & 32.4 \\
NTSS & 0.86 & 0.32 & 37.2 \\
\hline
\end{tabular}

It is clear that from table 7 the stiffness of treated samples is varied slightly from the original sample and sericin treated samples have good fabric stiffness when compared to nanosericin treated samples.
Table 7. Fabric Stiffness-Weft Direction

\begin{tabular}{llll}
\hline Samples & $\begin{array}{l}\text { Mean in } \\
\text { grams/sq.yard }\end{array}$ & $\begin{array}{l}\text { Loss or } \\
\text { gain } \\
\text { over } \\
\text { Original }\end{array}$ & $\begin{array}{l}\text { Percentage } \\
\text { loss or } \\
\text { gain }\end{array}$ \\
\hline UT & 0.69 & - & - \\
STS & 0.81 & 0.12 & 14.81 \\
NTSS & 0.74 & 0.24 & 32.4 \\
\hline
\end{tabular}

\subsection{Tearing Strength}

The fabric tearing tests for untreated and treated samples are given below.

Table 8. Tearing Strength - Warp Direction

\begin{tabular}{llll}
\hline Samples & Mean in gms & $\begin{array}{l}\text { Loss or } \\
\text { gain } \\
\text { over } \\
\text { Original }\end{array}$ & $\begin{array}{l}\text { Percentage } \\
\text { loss or gain }\end{array}$ \\
UT & 1804.8 & - & - \\
STS & 1843.2 & 38.4 & 2.08 \\
NTSS & 1856.7 & 51.9 & 2.79 \\
\hline
\end{tabular}

Table 9. Tearing Strength - Weft Direction

\begin{tabular}{llll}
\hline Samples & Mean in gms & $\begin{array}{l}\text { Loss or } \\
\text { gain } \\
\text { over } \\
\text { Original }\end{array}$ & $\begin{array}{l}\text { Percentage } \\
\text { loss or gain }\end{array}$ \\
\hline UT & 972.8 & - & - \\
STS & 985.6 & 12.8 & 1.29 \\
NTSS & 995.3 & 22.5 & 2.26 \\
\hline
\end{tabular}

In this tearing, strength has increased from the untreated sample to the treated sample with slight variation in these samples. Nano-treated sericin sample has good tearing strength when compared with the other two samples.

\section{CONCLUSION}

The woven fabric with polyester yarn has certainly poor water absorbency. When this fabric after treated with Nanosericin finish the rate of absorbency was increased to higher when compared to untreated fabric. Other fabric properties of the Nanosericin treated polyester fabric also improved. By this study, the absorbency property of the polyester fabric is improved. 


\section{References}

[1]. Freddi G., Mossotti R., and Innocenti R. "Degumming of silk fabric with several proteases," Journal of Biotechnology, Vol. 106, no.1, pp.101-112, December 2003.

[2]. Padamwar M.N., and Pawnar A.P. "Silk Sericin and its Applications: A review", Journal of Scientific and Industrial Research, Vol.63, pp. 323-329, April 2004.

[3]. Arunkumar K.V. "Degumming of Silk Yarn using Various Soap Method" International Journal of Multidisciplinary Research Centre, Vol.2 Issue.8, pp. 11-17, August 2016.

[4]. Zhang Y.Q., "Applications of natural silk protein sericin in Biomaterials," Biotechnology advances, Vol.20, pp. 91-100, May 2002.

[5]. Karpagam Chinnammal S and Arun Kumar K.V. "Nano Technology Application in Textiles" Journal of Nano Science and Nano Technology, Vol.2, Issue.4, pp 404406, Feb. 2014. 